\title{
RETHINKING DEMOCRACY
}

\section{RICHARD BOURKE}

School of History, Queen Mary University of London

E-mail: r.bourke@qmul.ac.uk

Jonathan Israel, Revolutionary Ideas: An Intellectual History of the French Revolution from the Rights of Man to Robespierre (Princeton: Princeton University Press, 2014)

John Dunn, Breaking Democracy's Spell (New Haven and London: Yale University Press, 2014)

In many respects these books, like their authors, are very different. John Dunn has spent his career as a professional political theorist calling into question the dominant idioms of his discipline. In addition to historical research on political thought and revolutions, and studies of contemporary West African politics, this enterprise has included exposing the assumptions of liberal and Marxist ideologies. Since the 1970s, running alongside this tremendous range of concerns, Dunn has also repeatedly returned to explore the history and theory of democracy. His latest book should be seen in the context of this extended preoccupation. It has its origins in the Stimson Lectures, delivered at Yale University in 2011, resulting in what the author describes as a compact study devoted to "a very large subject." Herein lies the first contrast with Jonathan Israel's new book. Israel has produced a large-scale intellectual history, building on a series of studies of the European Enlightenment, which began to appear at the start of the new millennium. Before that, Israel had written on colonial Mexico, European Jewry, and early modern Dutch history. It was his work on the Netherlands that led him to the thought of Spinoza, which then drew him to the ideas of the Enlightenment. As an Enlightenment scholar his approach has been characterized by a certain obduracy: a fixed commitment to a morally charged thesis. This approach can again be contrasted with Dunn's: while Dunn's book is a sceptical assault on moral complacency, Israel's is a more didactic performance, unflinchingly committed to the righteousness of its cause. As a result, ideology collides with dispassionate inquiry, arguably simplifying both.

$1 \quad$ John Dunn, Breaking Democracy's Spell (New Haven and London, 2014), ix. 
Purely on the level of scholarship, Israel's study poses a major challenge to existing accounts of the French Revolution. He begins by rejecting the old idea that the events of 1789 were principally caused by an economic crisis leading to social dislocation and then followed by political upheaval. It is true, he recognizes, that severe difficulties beset the administration of public finances in France on the eve of the Revolution. He also accepts that relations among the various components of French society triggered resentments throughout the course of the eighteenth century. However, neither financial exigencies nor social divisions are sufficient to account for the epic changes that Israel associates with the Revolution. As Revolutionary Ideas recounts the sequence of events, the steady collapse of the French monarchy from the summer of 1789 brought transformative political ideas like equality, human rights and popular sovereignty to the forefront of politics. The career of these ideas, Israel concludes, is alone capable of explaining the radical nature of the revolutionary developments that began in $1789 .^{2}$

Israel implies that historical commentary on the Revolution for much of the twentieth century was compromised by the commitment to vulgar Marxist principles. Some will argue that these principles had at best a tenuous relation to the social philosophy of Karl Marx, but it is nonetheless generally agreed that their dogmatic application to the interpretation of the French Revolution resulted in an account of social relations in eighteenth-century France that could not hope to explain political developments as these actually occurred. Israel thus sees his book as putting the final seal on the demise of a tradition of Marxist historiography that reigned through two-thirds of the twentieth century, from Albert Mathiez to Georges Lefebvre and Albert Soboul.

Here Israel is building on what amounts to an established consensus. But he goes further. Not only does he find doctrinaire attempts to trace the upheavals of 1790 os France directly to socio-economic causes wanting, but he also finds the more recent endeavour to explain the advent and progress of the Revolution in terms of cultural transformation inadequate. As Israel sees it, cultural histories of the Revolution have rather implausibly tended to ascribe revolutionary change to shifts in the character of popular discourse.

Israel has two problems with the kind of analysis that he associates with cultural accounts of the Revolution. He agrees with his opponents that the Revolution registered a radical shift in belief. However, he rejects claims that this shift was driven by campaigning hordes in the streets of Paris. It was not "the people" who generated the values that we have come to associate with the Revolution,

Jonathan Israel, Revolutionary Ideas: An Intellectual History of the French Revolution from the Rights of Man to Robespierre (Princeton, 2014), 11. 
Israel insists, but their leaders. On this account, the reigning ideas of 1789 and its aftermath were not developed by the foot soldiers in political clubs and around the Palais Royal, still less by the consumers of subversive tracts, but by the producers of enlightened philosophy who churned out pamphlets, posters and papers, and who would soon take the lead in the councils of the nation. ${ }^{3}$

Israel's second problem with cultural-historical approaches to revolutionary change derives from his doubts about the usefulness of "culture" as a category of historical explanation. Cultural historians have investigated an array of symbolic practices including festivals, oaths, iconography and so forth in order to recover the meaning of the Revolution. However, Israel contends that these practices are usually identified without an accompanying explanation of their causal significance. This is largely because they have been reconstructed without an examination of their intellectual content. If it is the case, as Israel believes, that the Revolution fundamentally altered concepts and values, then the historian is obliged to analyse the ideological content of political behaviour if we are to get any closer to understanding the process of change. This analysis has to go beyond the interpretation of an underspecified "culture" with a view to capturing the character of political argument, including the structure of its component ideas.

Israel's view is that the ideas of 1789 can be traced to the intellectual legacy of the Enlightenment. Here he is able to draw upon his own trilogy of works concerned with the development of a "radical" Enlightenment, published between 2001 and 2011. ${ }^{4}$ This succession of bulky tomes drew attention to a strain of radical philosophical doctrine inaugurated by the Dutch thinker Baruch Spinoza, and charted its progress through eighteenth-century Europe. Israel was principally interested in three aspects of Spinoza's thought: his rationalism, his metaphysics and his political ideas. As Israel analyses these, the first involved a commitment to strict deductive reasoning, the second a rejection of the dualism of spirit and matter, and the third an espousal of democratic republicanism.

Israel believes that these components were transmitted through the eighteenth century as a package of ideas. 5 Since each element is supposed logically to entail the other two, they constitute for Israel a systematically unified doctrine. In concrete terms, this means that strict mathematical reasoning will inevitably

Ibid., 355 .

4 Jonathan Israel, Radical Enlightenment: Philosophy and the Making of Modernity, 16501750 (Oxford, 2001); Israel, Enlightenment Contested: Philosophy, Modernity, and the Emancipation of Man 1670-1752 (Oxford, 2006); Israel, Democratic Enlightenment: Philosophy, Revolution, and Human Rights, 1750-1790 (Oxford, 2011).

5 Jonathan Israel, "Enlightenment! Which Enlightenment?", Journal of the History of Ideas, 67/3 (July 2006), 523-45. For comment see Anthony J. La Vopa, "A New Intellectual History? Jonathan Israel's Enlightenment," Historical Journal, 52/3 (Sept. 2009), 717-38. 
lead a philosopher to embrace a materialist metaphysics. This in turn will pit the thinker against the spiritualist assumptions of prevailing Christian doctrine. Antagonism to ecclesiastical establishments follows, along with opposition to reigning social and political authorities. A specific brand of irreligion, in other words, gives rise to political subversion in the form of democratic republicanism. As Israel sees it, it is this last political doctrine that began to prevail in France after the summoning of the Estates General in May $1789 .^{6}$

Accordingly, Israel sees modern history as having fitfully but nonetheless progressively fulfilled the process of logical entailment allegedly first diagnosed by Spinoza. On his reading, revolutionary activists and publicists like Condorcet, Sieyès, Mirabeau, Volney, Roederer and Desmoulins collaborated in the promotion of a set of philosophical doctrines dedicated at once to the destruction of religion and the advancement of democratic principles.

In his earlier work, Israel presented the irreligion of his radical enlighteners as premised on a single-substance monist approach to nature. In Revolutionary Ideas this claim seems to have been modified so that enlightened hostility to religion is construed more broadly as opposition to the idea of an active providence governing terrestrial affairs. ${ }^{7}$

On the face of it, this constitutes a fairly substantial revision: it is no longer just Spinozism that enjoys a privileged relation to the principles of democratic republicanism, but deism more generally. That, at least, is the argument presented in the Introduction to Israel's book: the "authentic" Revolution of 1789, as Israel terms it, "both rejected Christianity (whether from a deist or atheistmaterialist standpoint) and as a bloc abjured the principle of monarchy." ${ }^{8}$ Yet Israel's Conclusion is more in tune with his original thesis. Here we are told that the radical Enlightenment, which "caused" the Revolution, "is . . . best defined as the linking of one-substance monism with democracy and sweeping egalitarian social reform." 9

In any case, for Israel the essential point seems to be that what he terms the "left Revolutionary leadership" at once rejected Christianity and publicized the values of rights-based democracy. It is this leadership that Israel believes embodied the "true" spirit of the Revolution. Divergence from their doctrines was seemingly a corruption of the authentic message. It follows for Israel that the Jacobinism of the Montagne, and above all what he describes as Robespierre's "putsch" of June 1793, constituted a consummate betrayal. On this reading, the Revolution was advancing by means of argument and publication, only to be subverted by a

Israel, Revolutionary Ideas, 703.

Ibid., 22.

Ibid., 29, original emphasis.

Ibid., 703. 
brand of "authoritarian populism" exemplified by the philosophy of Robespierre and his followers. ${ }^{10}$

Publication is an important process for Israel. His aim is to show how a particular ideology, the ideology of modern democratic republicanism, gained political traction. He pursues this by exploring the circulation of ideas. He thus accepts the criticism of cultural historians commonly levelled against intellectual history to the effect that its preoccupation with the structure of political argument encourages abstraction from the practical employment of ideas. It is generally accepted by historians that systems of belief-like protestantism, experimental science, communism and feminism-have dramatically affected the shape of history. The question, of course, is how these effects have been achieved. For Israel the answer is dissemination.

The study of dissemination demands that two questions be addressed together: first we need to ask what the character of the ideas being propagated is, and second we need to investigate how those ideas are diffused. Israel may be right that historians of political thought since the 1960s have addressed themselves to the former question without having enough to say about the second. If we are to explain how beliefs transform societies, then we have to understand how the process of change operates. When public opinion is affected, the historian needs to show how intellectual innovation is in practice broadcast and generally adopted.

Given his commitment to the study of dissemination as the principal means by which the "uptake" of intellectual innovation is given broad circulation, it is interesting that Revolutionary Ideas stumbles in its account of the diffusion of concepts. Two aspects of the process in particular are confused. First there is a problem with Israel's account of how revolutionary principles were accepted, then there is a problem with his analysis of the principles themselves.

For all his apparent concern with diffusion, Israel informs his reader that intellectual ferment in France between 1788 and 1793 was either opposed or "uncomprehendingly regarded" by the vast majority of the population, and indeed by a majority within the National Assembly. ${ }^{11}$ This amounts to saying that the revolution in ideas, which his book wants to trace, occurred in the absence of popular support. To begin with this implies that appropriately "radical" ideas were not disseminated, and therefore that the doctrines promulgated by what Israel sees as the authentic Revolutionary vanguard lacked what we might call democratic endorsement. It is consequently hard to understand how the principles of equality and human rights supposedly advocated by Brissot, Sieyès, Mirabeau and company constituted an unproblematically democratic

\footnotetext{
$10 \quad$ Ibid., 695.

11 Ibid., 16.
} 
doctrine. Israel's difficulty with diffusion becomes a problem for the conception of democracy that drives the direction of his research.

Israel then has a further problem with the character of the ideas whose circulation he wants to trace. This consists in the fact that he presents those ideas in such overwhelmingly generalized and abstract terms that careful historians will be very slow to rely on his analysis.

For instance, he presents the advocates of what he sees as "correct" revolutionary change as single-mindedly committed to republican ideology. But of course what a republican conception of the state had come to mean by 1788 in Europe was a complex and highly nuanced thing. Because that complexity does not fit with Israel's purpose, he is forced to squeeze his protagonists into the narrowest of frameworks when in fact they held a variety of views which usually developed over time. Recognizing some of this variety, Israel is forced to concede that a number of his prime republican publicists were only democratic "in the main" or even, like Mirabeau and Sieyès, only "to an extent." ${ }^{12}$ It is not at all clear that this amounts to an identifiable position.

Israel's project in Revolutionary Ideas began with enormous promise. His goal was to restore ideological conflict to its central place in the Revolution and its aftermath. ${ }^{13}$ In pursuing this objective, he might have begun by seriously engaging with the work of other historians in the field-Keith Michael Baker, Pasquale Pasquino and Michael Sonenscher prominent among them. ${ }^{14}$ At a minimum, this would have to involve considering their readings of particular authors and texts. Instead, Israel very much steers his own course. The accounts of canonical works that emerge are rarely grounded in careful exegesis. As a result, his interpretation and analysis of the relevant ideas are often so radically Procrustean in nature as to cast doubt on the credibility of his conclusions. His dramatis personae are organized into starkly antagonistic phalanxescounter-Enlightenment, moderate Enlightenment and radical Enlightenment camps. Voltaire, Rousseau, Hume, Burke and Montesquieu are all assigned to the moderate wing. Yet to anyone who has worked in a sustained scholarly way on any of these figures, it is often their differences rather than their shared purposes that are both striking and interesting.

12 Ibid., 29.

13 This aim is foreshadowed in Jonathan Israel, A Revolution of the Mind: Radical Enlightenment and the Intellectual Origins of Modern Democracy (Princeton and Oxford, 2010).

14 These names all appear in Israel's bibliography, but rival interpretations are rarely signalled or discussed. Equally, primary works are invoked or epitomized rather than meticulously explicated. 
Despite these differences, Israel is confident that moderate enlighteners effectively paved the way to reaction. Rousseau, or at least an impoverished rendition of Rousseau, is singled out here as a major culprit. Robespierre, Danton and Marat, along with an assortment of Montagnard associates, are portrayed as recycling a version of his sentimentalism and combining it with a rabid populism that culminated in the Terror. ${ }^{15}$ The progenitors of the socalled radical Enlightenment, on the other hand, apparently pointed towards the future, which happened to coincide with Israel's preferences. By his own account, they did this in the absence of popular consent, hoping in the end to educate a following whose customs they meanwhile held in contempt. We are left with a strange conception of democracy, and a curious vision of history.

\section{$* * *$}

Dunn's new book is not a history, but it is written with more historical sensibility. One might best describe it as a series of reflections focused on the question of democracy's appeal. In presenting its case, it cuts across many of the conventional assumptions that have dominated anglophone political thinking over the course of the past half-century. Throughout that period, the study of politics has been dominated by two antithetical approaches-positivistic political science on the one hand, and normative political theory on the other. Dunn's voice has been a singular one in resisting both these tendencies. He has promoted instead a historical mode of analysis that is sensitive to the inescapably normative character of political life, yet averse to the reduction of political philosophy to decontextualized moral analysis. His successive explorations of the meaning of democracy exemplify this style of argument.

Breaking Democracy's Spell sets about investigating the lure of democracy first by exploring the charisma implicit in its steady rise, and then by ascertaining the limits of its ability to tackle the most pressing problems facing the world today. The book begins by drawing a stark contrast between the self-satisfied official ideology of democracy and the misery that afflicts large sections of society in democratic states. Misery, of course, is a relative concept-but that's Dunn's point. In this connection he draws attention to "the hideous disparities between our destinies as individuals, families, and classes." ${ }^{16}$ Yet this adverse situation is commonly presented as the best of all possible worlds, resulting, on the one hand, from an economic system that seeks to extend prosperity based on freemarket choice and, on the other, from a political system that safeguards the general welfare by subjecting politics to the people's will. What has brought this

\footnotetext{
15 Israel, Revolutionary Ideas, $450 \mathrm{ff}$.

16 Dunn, Breaking Democracy's Spell, 1.
} 
false sense of security about? For Dunn, it is the idea rather than the reality of democratic government that accounts for much of this complacency.

While Breaking Democracy's Spell begins with the observation that the modern world has in some sense been "bewitched" by democracy, it proceeds to subject its apparent charm to critical interrogation. ${ }^{17}$ It pursues this task along two distinct tracks - first, rather briefly, by engaging in comparative political analysis; and second, in a more sustained way, by juxtaposing the normative appeal of democracy with its actual procedures and results.

The comparative aspect of the book largely involves setting the familiar workings of American democracy alongside Indian and Chinese politics. The two latter cases are of course radically distinct, but they both serve a common objective, which is to challenge the assumption that Western democracy is the inevitable expression of good government. In taking issue with this perception, Dunn's aim is to highlight the extraordinary parochialism that dominates modern political theory, which habitually mistakes local preferences for international norms. In asking his reader to engage with historical trajectories other than those of Europe and America, his object is to diminish the insularity that afflicts Western political thought.

His target here is the intellectual and political elite in the United States in particular. One of the legacies of America's struggle with the Soviet Union has been a pervasive sense of righteousness that prizes abstract political value over contingent accommodation to circumstance. Historical reflection on Indian democracy leaves us with a less pious sense of political accomplishment. It is, of course, the case that the endurance of democracy on the colossal scale of the Republic of India represents an extraordinary triumph. Yet this achievement has persisted in the face of such powerfully countervailing forces that it would be impossible to mistake this haphazard process for the realization of national destiny.

The fortuitous character of political development in India is a standing lesson against the moralizing conceit that associates a particular type of government with a universal norm. Consideration of the course of Chinese history tends towards the same result. The intimate connection between social organization, public opinion and regime form in China needs to be understood in its own terms, rather than as a deviation from some "appropriately" democratic path. The achievement of prosperity, security and toleration should count for more than the notional benefits of an abstract system of government.

This is particularly the case where these notional benefits are found wanting in practice. Insofar as democracy is associated with good government, one might

$17 \quad$ Ibid., 6. 
legitimately expect from it a proven record of judicious decision-making. Yet it makes little sense, Dunn argues, to embrace democracy as peculiarly fitted to dealing with the manifold problems of ecological degradation and economic instability that affect our shared environment. Democratic governments have no particular claim to deliberative wisdom or practical insight.

Here Dunn's argument is less exclusively concerned with the problems of democratic government per se than with the difficulties that beset political judgement more generally. Dunn's claim is that popular deliberation is not immune to the deformations of judgement observable across the historical span of political forms of life. In his Cunning of Unreason, which appeared in the year 2000 , he described the modern democratic republic as commonly subject to two rival descriptions. Under the first, it is a means of unconstrained citizen choice whereby "the people" more or less determine their destiny directly. Yet under the second description it appears altogether more passively, less as a vehicle for popular choice than as a "local implementation device" impelled by the forces of international commerce. ${ }^{18}$ If democracies are best seen as combining these characteristics, as exercising agency within a heavily determined field of force, Dunn's point is that this agency is more haphazard than acute. In other words, democracies have no privileged access to political perspicacity.

This conclusion is not intended to challenge the credentials of democracy by comparison with other possible regime forms - neither monarchy nor aristocracy can pretend to better processes of decision-making. If anything, Dunn accepts the Aristotelian point that common deliberation stands a better chance of success than more narrowly based forms of practical judgement. Yet this brings Dunn to reflect on the real deficiency of modern democracy, namely its pervasive justification on the basis of a false promise. Democracy pretends to institutionalize rule by the many, but in fact in its modern guise it rather resembles rule by the few. Dunn once described aristocracy as "veiled or blatant inequality of political access." ${ }^{\prime 19}$ The idea of political "access" is a very generalized one, but if it is meant to imply the actual activity of ruling then it is clear that modern democracies amount to a system of veiled inequality. Dunn has long contrasted this modern arrangement with ancient practice, and so his latest statement of the position needs to be seen in a wider frame.

Dunn's earliest published treatment of democracy goes back to the 1970s. It was in Western Political Theory in the Face of the Future that he first articulated the view that many aspects of modern democracy more nearly resemble oligarchies

18 John Dunn, The Cunning of Unreason: Making Sense of Politics (London, 2000), 353.

19 John Dunn, "Capitalist Democracy: Elective Affinity or Beguiling Illusion," Daedalus, 136/3 (Summer 2007), 5-13, at 13 . 
than befits a system devoted to rule by the many. ${ }^{20}$ Here he was responding to what were then called "elitist" theories of democracy advanced by thinkers like Joseph Schumpeter, Seymour Martin Lipset and Robert Dahl, which at once described and justified modern democratic government as a competition for power in which sectional interests prevailed over an inclusively defined demos. Schumpeter in particular associated democracy with competition for votes between rival parties, which in turn selected leaders to govern passive populations. This description was presented as a social-scientific fact, yet for Dunn it wore the appearance of a normatively inflected judgement. It was, as he put it, "dismally ideological," a vindication of the oligarchical structure of nominally democratic government masquerading as a neutral presentation of how things were. ${ }^{21}$

Yet in Dunn's eyes the Schumpeterian account at least had the merit of engaging with an existing form of government. Then, as now, its chief rivals came in the shape of theories of democratic deliberation and participation, variously commended by thinkers like Jürgen Habermas and Carole Pateman. These "utopian" theories, as Dunn dubbed them, depended on a commitment to an ideal of political equality that is simply inoperable in the context of concentrations of power characteristic of modern systems of government. ${ }^{22}$ Following Moses Finley, whose Democracy Ancient and Modern had appeared in 1973, Dunn contrasted the utopian expectations that animated most theorists of participatory democracy with the civic practice of ancient city states, above all Athens. The "Athenian demos ruled, held political power in Athens," as Dunn put it. ${ }^{23}$ By way of contrast, modern democracy had witnessed a "drastic reduction in the element of popular participation," as Finley emphasized. ${ }^{24}$

Dunn has long been fascinated by the allure of ancient democratic practice, or more specifically by the value of self-government that it seems to have embodied. He has been equally interested in the revival of that ideal under the shadow of the modern state. However, by the 1990s his emphasis had shifted. In the Conclusion to his edited volume on Democracy: The Unfinished Journey, Dunn continued to underline the remoteness of the ideal of participatory democracy from practical politics in the modern world. From this perspective, the efficacy of representative government did not lie in its deliverance of a system of self-rule but rather in the semblance of self-government that it offered. In no credible sense did the citizens of modern democracies literally rule, but in authorizing governments, and in

John Dunn, Western Political Theory in the Face of the Future (Cambridge, 1979), 26.

Ibid.

Ibid.

Ibid., 16, emphasis in the original.

24 Moses Finley, "Preface" (1984), in Finley, Democracy Ancient and Modern (New Brunswick, NJ, 1985), ix-x, at ix. 
calling them to account, they enjoyed a better claim to embodying the ideals of democratic politics than any other viable competitor in the field. In combining at least a plausible appearance of self-government with the demand for subjection on which the modern state was premised, representative democracy might be described, as Dunn phrased it, as a "conjuring trick," but it was still, as he went on to concede, a ruse that any sober judge ought to hope would continue. ${ }^{25}$ If modern democracy was in some sense an oligarchical concoction, at least it had the advantage of ensuring stable property relations together with effective means of holding rulers to account. ${ }^{26}$ This arrangement falls far short of social justice and equal power, yet for Dunn it was nonetheless preferable to the available alternatives that pretended to offer these benefits while engineering their eclipse.

Yet while Dunn has come to accept the forms of subjection integral to representative democracy, he still continues to lament the loss of autonomy that this entails. This tends to leave his argument suspended between two polesrelentlessly committed to realist political judgement yet residually dissatisfied with the result. In this vein, Breaking Democracy's Spell accepts the discipline that representative government imposes on its citizens while proceeding to regret the loss of freedom that this involves. The regret is evident in Dunn's valuation of the promise of popular control implicit in democracy's appeal. It is, he writes, "an all but vacuous gesture in exchange for a dismayingly complete alienation of autonomy." 27

To the extent that this gesture is indeed vacuous, Dunn thinks that it threatens to diminish the efficacy of democracy insofar as it encourages citizens to overinvest in its potency. This is liable to blind us to two facts, Dunn believes: first, the perishable nature of representative democracy, and second, its inability to guide collective life. Yet equally Dunn never denies that these are general features of politics, both products of flawed intelligence and the impermanence of things. Breaking Democracy's Spell argues convincingly that democracy is no more than a historical accident, and that as such it is vulnerable to disintegration under domestic and international pressures. Circumstances brought it into existence, and circumstances might equally bring it to an end. It is not clear to what extent Dunn thinks we should bewail this possible outcome, not least given what he views as the fraudulent character of current arrangements. If democracy promises

25 John Dunn, "Conclusion," in Dunn, ed., Democracy: The Unfinished Journey (Oxford, 1992), 239-66, at 249.

26 John Dunn, "Situating Democratic Political Accountability," in Adam Przeworski, Susan C. Stokes and Bernard Manin, eds., Democracy, Accountability, and Representation (Cambridge, 1999), 329-44.

27 Dunn, Breaking Democracy's Spell, 20-21. 
freedom but actually delivers subjection, on what basis might we want to shore up its future?

Dunn analyses popular subjection in terms of three Weberian principlesthe utility, or rationality, of submission to a system of rule; the charisma of the promise to empower the populace; and acquiescence in government based on its traditional appeal. ${ }^{28}$ For Dunn, much hangs on the force of tradition in established democratic regimes, although the charisma of what looks like self-government offers additional enchantment. Utilitarian calculation, or the rationality of submission, plays a considerably smaller role in Dunn's account. This is largely a result of his assessment of the modern contract of government, which turns on a sort of fiction of popular empowerment. Democracy, Dunn writes, is essentially "a formula for imagining subjection to power and the will of others without sacrificing personal dignity." ${ }^{29}$ The implication is that a sacrifice of autonomy in fact occurs.

Breaking Democracy's Spell vividly contrasts the prevailing ideal of autonomy in American society with the reality of its economy and polity. Important strands of libertarian thought celebrate the prospect of untrammelled entrepreneurialism while the dominant idioms of liberal philosophy champion the cause of equal respect. Both sets of values differently invoke a common norm of selfdetermination. Dunn's suggestion is that there is something deeply disingenuous about the claim that capitalist democracies might ever realize this goal. Yet does the disparity between Western societies and some of the more grandiose ideals that they continue to host license the conclusion that the democratic pact of subjection is ultimately a fraud?

The answer to this question obviously depends on how we evaluate the forms of submission that representative democracies require. Dunn's assessment tends to turn on the contrast with ancient Greece. As he wrote in Setting the People Free in 2005, the "citizens of Athens in the fifth and fourth centuries BC, to a now bewildering degree, governed themselves." ${ }^{30}$ Of course it is right that Athenian offices alternated among ordinary citizens, and that its Assembly was a forum comprising the demos at large. But it does not follow from this that power was distributed equally or that politics was an exercise in collaborative agency. Above all, it could not be said that allegiance came without subjection. The division of political labour in ancient democracies differs starkly from arrangements under modern regimes but the contrast cannot be fully captured by the radical antithesis between autonomy and subjection. Politicians certainly rule in representative democracies, but their populations cannot be said to be

Ibid., 26-7.

Ibid., 14.

3o John Dunn, Setting the People Free: The Story of Democracy (London, 2005), 18. 
in a state of submission to them. Plato complained that leaders merely followed their supporters in Athens. Despite the conclusions of Schumpeterian sociology, the chiefs of modern democracies are significantly dependent on their adherents.

$* * *$

Israel and Dunn offer strikingly divergent visions of politics. Israel sees democracy as the product of ideas first formulated in the seventeenth century, which then began to conquer politics by the force of their intrinsic truth. It is a tale of heroic, deliberate ascent, marred only by resistance from superstitious reactionaries. For Dunn, on the other hand, the rise of democracy has been an altogether more contingent affair, the product of successively defeated ideals, now promising more than it can ever hope to deliver. For both authors the French Revolution was a pivotal turning point, the moment at which recognizably modern values were given efficacy. Both books serve to remind us of the elusiveness of those values, inviting their readers to reconstruct their past. Dunn ends with a call for the research community to probe deeper into history, the better to understand what democracy has become. Israel appears more confident that the story of democracy is already to hand. Having embarked on the bold and necessary enterprise of charting the intellectual history of the French Revolution, he leaves his reader doubting the credibility of his conclusions, and reflecting that historians will have to begin the task gain. 